\title{
The Perception of Perhumas Central Java Members on Principles of PR Performance in Islam
}

\author{
Persepsi Anggota Perhumas Jateng \\ tentang Prinsip Kinerja PR dalam Islam
}

\author{
Trimanah $^{1}$, Diah Wulandari ${ }^{1}$ \\ ${ }^{1}$ Study Program of Communication Science, Universitas Islam Sultan Agung Semarang, \\ Jl. Kaligawe Raya Km. 4, Terboyo Kulon, Genuk, Semarang 50112, Indonesia \\ *Corresponding author, e-mail: trimanah@unissula.ac.id
}

\begin{abstract}
Public Relations as a matter of study and implementation of theory, can not be separated from the influence of religious scriptures embraced by individuals. For a Moslem, the Qur'an and Hadith are the guides and sources of knowledge that are used as a reference by Public Relations Officer in the work. Arthur W. Page proposes work principle that must be owned by Public Relations: Tell the Truth, Prove It with Action, Listen to the Customer, Manage for Tomorrow, Conduct Public Relations as If The Whole Company Depends on It, Remain Calm, Patient and Good Humor. This research discusses about the Perception of Perhumas Central Java Members in viewing the principles of public relations performance in Islamic Shari'a view. The method used in this research is descriptive qualitative, using 4 informants. Analytical techniques used are interactive analysis model, data collection was done by structured interviews and literature study.
\end{abstract}

Keywords: Public Relations, Principles of PR work, Islamic Shari'a.

\begin{abstract}
Abstrak
Public Relations sebagai bahan kajian dan implementasi teori dalam praktis, tidak terlepas dari pengaruh kitab suci agama yang dianut oleh setiap individu. Bagi seorang muslim, Alquran dan Hadits merupakan pedoman dan sumber ilmu yang dijadikan rujukan oleh Public Relations Officer dalam bekerja. Arthur W. Page mengemukakan prinsip kerja yang harus dimiliki oleh Public Relations yaitu: Tell the Truth, Prove it with Action, Listen to The Customer, Manage for Tomorrow, Conduct Public Relations as If The Whole Company Depends on It, Remain Calm, Patient, dan Good Humor. Penelitian ini mengenai bagaimana Persepsi Anggota Perhumas Jawa Tengah dalam memandang prinsip kinerja public relations dalam pandangan syariat Islam. Metode yang digunakan penelitian ini adalah deskriptif kualitatif, dengan 4 orang informan. Teknik analisis yang digunakan adalah model analisis interaktif, pengumpulan data dilakukan dengan wawancara terstruktur dan studi pustaka.
\end{abstract}

Kata Kunci: Public Relations, Prinsip Kerja PR, Syariat Islam.

\section{Copyright () 2018 Universitas Semarang. All rights reserved.}

\section{Introduction}

Public Relations (PR) is about how to build mutual communication between the organization and its public continually and continuously with the aim of obtaining goodwill, mutual understanding, trust, cultivating positive public opinion, gaining public support, all of which will lead to the reputation of the organization (Syuderajat and Prameswari, 2017: 186). This is in line with the opinion of Institute of Public Relations (IPR) which states that "PR is the overall efforts done in a planned and 
sustainable way in order to create and to maintain goodwill and mutual understanding between an organization with all its members" (Jefkins and Yadin, 2002: 9).

Overall, the purpose of public relations is to create good image of the company to generate public loyalty to the products offered by the company. In addition, public relations aims to create, nurture and maintain favorable attitude for the institution or organization on one hand and with the public on the other hand with harmonious and reciprocal communication (Mubarok and Dian, 2016: 21).

In the effort to build reciprocal communication with its public, it is the PR Section or the PR Department that functionally has the role as communicator as well as mediator for the organization to convey positive messages from the organization to its public, either internal or external public. For that reason, Public Relations Officers (PRO) or PR officers are required to be professional and always be a person who must be all-know, all-conscious, fast paced in response to any signal that has the potential impact on the organization.

To be a good and professional PRO, at least they must have eight principles of PR work as written by Arthur W. Page, i.e Tell the Truth, Prove It with Action, Listen to The Customer, Manage for Tomorrow, Conduct Public Relationss as If The Whole Company Depends on It, Remain Calm, Patient and Good humor.

Islam, is a religion that strongly emphasizes the importance of maintaining relationships built on the basis of mutual understanding, justice and honesty. This is certainly in line with the principles of PR work as proposed by Arthur W. Page above and also by the other experts and PR experts. So there is very close relationship between the principles of PR work and Islamic teachings contained in the Qur'an and Hadith. Therefore, PR as a study material and the implementation of theory in practice can not be separated from the influence of religious scriptures embraced by every individuals involved in communication, especially those who work as PRO.

Members of Central Java Public Relations Association are practitioners and public relations academics who are predominantly Moslem. They have obtained provision of religious understanding (Islam) from their childhood as the foundation of thinking and acting. They also have knowledge and experience in the field of Public Relations, both obtained formally and informally. Religious background, knowledge, and experience must have shaped their perception of how good and professional work principle in their profession as public relations academics and practitioners.

This study aims to find out the perceptions of Perhumas Central Java members on PR performance principles according to Arthur W. Page which includes the principles: Tell the Truth, Prove It with Action, Listen to the Customer, Manage for Tomorrow, Conduct Public Relationss as If the Whole Company Depends on It, Remain Calm, Patient and Good humor, in the view of Islamic Shari'a.

The benefit of this study is as input in the treasury of communication science theory, especially Public Relations that local and religious wisdom derived from the Qur'an and Hadith have effects in the development of theory and practice of Public Relations for a Moslem.

\section{Methodology}

This study was conducted among the Members of Perhumas (PR Association) Central Java, with the consideration that (1) the members of Perhumas are the professionals working according to PR rules and principles, (2) the average members of Perhumas Central Java are Moslem. 
Based on the problem proposed in this study, that is about perception, hence the research type chosen is descriptive qualitative. This type of research can interpret and describe the data concerned with views that occur in a group of people. The qualitative research method with descriptive approach used in this research is in accordance with what is delivered by Nazir (1988), which states that descriptive method is a method in examining the status of a group of people, an object, a set of conditions, a system of thought or an event class in the present time. In line with what was delivered by Sugiyono (2012) which stated that the qualitative method presents directly the nature of the relationship between researchers and informants, objects and subjects of the research.

The steps taken in this study is by searching and compiling the data obtained from interviews, field notes and documentation systematically, by organizing data into categories, describing into units, synthesizing, arranging into patterns, choosing which one is important and that will be learned, and making conclusion so that easily understood by oneself and other people (Sugiyono, 2012).

Analytical techniques in this study were conducted by following the interactive analysis model (Miles \& Huberman, in Sutopo, 2006: 113). In this study there are three components of analysis, namely data reduction, data presentation and conclusion making. This process continues throughout the study.

Data reduction is the process of selecting, sharpening, classifying, disposing of the unnecessary, organizing the data in such a way that the final conclusion can be drawn. The presentation of data was done in the type of sentence narrative. While the conclusion was done by performing complete configuration that was verified so that the data obtained can really be accounted for by reviewing the data obtained previously with quick data retrieval or discussion. Data were collected using structured interviews and literature studies.

To ensure that the data collected is authentic, the data validity must be performed. In this study, data validation was done by using data or sources triangulation technique. This technique allows researchers to use various available resources. Researchers used different types of data sources and evidence from different situations. This study used several sub types, namely; people (informants) those who have the same profession and joined in Perhumas Central Java; time, where data were collected at different times; and space, where data were collected at different places according to the place where the informants were working as PR practitioners.

\section{Result and Discussion}

In this study, researchers have selected 4 members of Perhumas Central Java as informants. The four are Moslem and work as PR in 4 different institutions, namely: State Universities, Private Islamic University, Mass Media, and Islamic Hospital. From the four informants who have different backgrounds, more complete information are expected to be able to be collected, based on the religious understanding and experience they have in their workplace.

The questions about the principles of public relations performance by Arthur W. Page were asked to the four informants, which includes the principles:

1. Tell the Truth (never Lie).

2. Prove It with Action (verification in Behavior/Action).

3. Listen to the Customer (Listening to Customer/Public).

4. Manage for Tomorrow (Management for Tomorrow/Time Management). 
5. Conduct Public Relationss as If the Whole Company Depends on It (Conducting Public Relations as if the Whole Company depends on It).

6. Remain Calm (Calm in all Situations).

7. Patient.

8. Good Humor.

The answers they gave of course refered to what they did and they understood about Islamic law related to the principles of PR work according to W. Page above.

a. The Understanding of Islamic Shari'a

The answers of the four informants illustrates that the work principle of the informants are influenced by the religious teachings they profess, namely Islam. For the first question proposed, namely: "Do you agree that the principle of $P R$ work is in accordance with the teachings of Islam?" All informants agreed. As suggested by the second indorman stating that:

"Because I am a Moslem, so the foundation of my life rests on the Qur'an and Hadith which become my guides"

Not much different from the second informant, the third informant answered clearly "although not memorized the verses of Qur'an and Hadith that affirm the public relations, but I know there are arguments that the concepts are: conveying something true, making good humanity /community relationships etc which are the main tasks of a public relations."

Another informant stated that "Those values greatly influenced me indirectly as a journalist (who arguably a public relations as well) especially the principles of tabayyun (if I am not mistaken as recommended by Qur'an Surah Al-Hujarrat verse 6). The principle of leaving the affairs to the experts is also always applied when we are looking for sources, also the principle of telling the truth in the news."

From the answers of these informants, it can be concluded that Islamic teachings have influenced their perspective on work. They understand well that what is done by a $\mathrm{PR}$ is in line with what is taught by Islam as stated in His verses and in hadith. Islam highly respects silaturrahmi and maintains good relations, then the essence of PR is to establish two-way mutual relationship to gain mutual understanding and to get goodwill. b. Work principle of PR According to Arthur W. Page

To get good relationship between the organization and its public in order to build reputation, maintain the image, and cultivate goodwill, then Arthur W. Page formulated 8 work principle of a PR. The followings are the answers of the informants when they were asked about the work principle, are they in accordance with the teachings of Islam?

1. Tell the Truth

In the work principle of PR, honesty is the main principle. Despite having the task to build image, to encourage positive public opinion, and to maintain the good name of the organization, in any condition a PR can not lie, moreover manipulate the data and conditions that exist. Tell the truth is the first principle.

The informants pointed out that they all had the awareness to convey the truth in accordance with what really happened. Public Relations should not lie, but in delivering message to the public should be done by looking at the needs of the public for the information. This means that only the information needed by the public is delivered, unneeded messages should not be conveyed.

There is not problem to convey good things from the organization because PR always tries to do the best and puts forward honesty in every words, actions, and deeds. 
Although the facts conveyed are inadequate or unfavorable in forming opinion or image, then without neglecting the matter of the truth delivery, a PR should give certain argument that confirms the deficiency. In short, the PR should still convey the truth but with additional arguments that as far as possible can be understood by the public.

It can be concluded that a PR can not lie. But in certain circumstances where there are negative things happened to the organization, a PR can do the delivery of argumentation, by giving an explanation about what and how it happened. The point is, without lying a PR can still convey positive things about the organization by conveying the facts that occur and conducting the argument that can be accepted public when there are things that need to be clarified.

\section{Prove It With Action}

The second principle of PR according to Page is prove it with action. What conveyed by a PR about his organization must be proven by real action / deeds / outcome. This involves prooving on what they have conveyed. In Islam, between words and deeds must be in line. If not, then Islam calls it hypocrite or lie.

One of the informants stated that anything delivered by a PR should be able to be proven, because it is part of building stakeholder trust. There must be consistency over what is delivered and what is done, so that stakeholder can trust the PR and the organization.

Another informant even gave a very basic answer to the nature of telling the truth. Because according to him God is always there and watches over whatever he does. Therefore the action must be in accordance with what is said. If not, then Islam puts it into the group of hypocrite people. The signs about which is good and right, which may and should not be done by a PR is related to the suitability between words and deeds derived from his devotion to the teachings of Islam greatly affect the working principle of the second informant as a PR, especially in terms of honesty.

Other informant provided answer by relating it to the coordination done with the management. For him, the key to prove it with action is coordination. Surely this is closely related to the answer of the previous question about tell the truth. To provide concrete evidence of what is being conveyed, what must be seen first is what management has done and will be done, so the message is true.

\section{Listen to the Customer}

The sustainability of the organization highly depends on the public. Therefore, their will must be heard. Islam also teaches about the importance of listening. As the Prophet always gives an example of how he always listens to his friends in doing something or deciding various things. In the process of listening the Prophet can understand the various problems that occur in his people. Many verses of Allah came down after the listening process done by the Prophet. The verses of Allah came down gradually, according to the conditions of the Moslems. These conditions were widely known by the Prophet through the process of listening.

The first informant answered that to listen to public expectations and will to the organization, the channel or public service should be opened. From what is conveyed by the public, PR then works dynamically to solve problems, handle complaints or inputs that are feasible and need to be acted upon for the good and reputation of the organization.

The second informant put more emphasis on the effort of conducting research, which is part of the effort to understand and to know the public will. It also opens up dialogue with the public through the availability of channels for feedback, meeting 
directly with the public, conducting activities that bring openness. Activities such as gathering or thank's day are important things to do to listen to more aspirations from the public.

The third informant, again, replied with the glasses of a journalist who is also a member of Perhumas. For him, listen to the custommer is code of conduct (play role) in the work of journalism. Contextually, the essence of the role of the mass media in its attempt to understand what the public wants. Without listening to the will of the public then certainly a media will not produce news that many public read. If so, then the media should prepare to be left by it readers. That means, PR should be able to capture the message signals from the public then they should be conveyed to the management and reporters in the field, to be able to present the news in accordance with what is needed by the public.

In contrast to the answer of the third informant, the fourth informant put more emphasis on the effort to follow up the input from the customer after going through the screening process first. Especially if the input involves other units or professions, then what is done is coordination, even to the top level management.

The three previous informants answers emphasised more on the efforts to accommodate the wishes, hopes and desires of the public through dialogue efforts and opened channels of communication to obtain public signals and feedback, the fourth informant answer had point of emphasising on the reaction on what is conveyed by public.

4. Manage for Tomorrow

Jeffkins states that "PR is all kinds of planned communication, either inward or outward, between an organization and all its public in order to achieve specific goals based on mutual understanding" (Jeffkins and Yadin, 2003). Islam also teaches about the importance of planning for tomorrow.

The first informant conveyed the answer that time is a simple target that must be achieved in conducting every activity. Time management is very important to be held firmly by the actors of public relations, because a neat time management will foster stakeholder trust in the organization.

In line with the first informant's answer above, the second informant also highly regarded the importance of time management, and time management must be based on research. The success of a PR in carrying out his work is largely determined by the arranged plan. This second informant even quoted the hadith of the Prophet who stated "direct your dreams like arrows that you direct as high as the stars in the sky, then if not materialized you still get the highest." Therefore in planning it is important to plan the best so that good results can also be obtained.

From this second informant's answer, it can be concluded that planning for tomorrow must be made as well as possible, as taught by Prophet SAW. With good planning, surely the opportunity to produce the best will be greater.

The third informant gave the answer according to the culture developed in the media organization. In the media organization, time is highly honored with the term deadline. Therefore, time management really needs to be mastered by anyone who works in the media industry, including PR. While the fourth informant stated that in working as PR, one should be able to balance between time to work and time for God. That no matter how hard a PR works and divides the time, there must be time for the business of the afterlife, for he believes that God is in control of the time of his servants.

Jurnal The Messenger, Vol. 10, No. 1, January 2018, pp. 124-134 
5. Conduct Public Relations as if the Whole Company Depends on It

It can be said that the heart of the organization is in PR. If the PR is not able to perform its function in maintaining the relationship with the public, then it means the heart can not pump and drain the blood throughout the body of the organization. For that a PR should have the awareness to work wholeheartedly as if the entire company relies on PR.

Related to this principle, the first informant considered that the PR department should really be able to maintain networking. Because with good networking, it will bring trust and recognition from the public. The good name of the organization depends on PR in building trust and positive image.

The second informant stated that "silaturrahmi" (building relationships) will add to sustenance and blessing. Therefore, according to him, a PR in his activities must often make efforts to build relationships by meeting and opening themselves to the others so it will be easier to build trust and recognition from the public, because they (public) know that we have goodwill and principle of "ana rembug ya dirembug" in the context of local wisdom of Java that needs to be upheld in PR activities. Because the core of PR profession is wholeheartedly have good intentions built so that it will manifest in everything that is done and the impact will be felt by the organization.

In line with what the previous two informants said, the third and fourth informants generally stated the same thing as the previous two informants. Especially for the fourth informant, who added that the success of a PR in carrying out his duties and functions in building the good name of the organization also can not be separated from the support of organizational management. This means that the success of PR in maintaining the good name of the organization through the fabric of relationships built over sense of mutual understanding, can not be said as merely public relations success, but there is the role of management that together achieve the goals of the organization in growing the reputation. This means that the success of establishing good name of the institution does not only belong to PR, but there is a team work that involves cross-section within the organization, where management plays a role in this case.

6. Remain Calm

Islam teaches its people to be calm in facing various situations and conditions. We must remain calm. It is impossible to imagine what if a PR works hastily, "grasa grusu" without consideration and calculation, while the good name of the organization highly depends on the level of carefulness of a PR in looking at all situations carefully.

Associated to this principle, the first informant suggested that indeed, a PR is required to work not only hard but also smart, quiet, not reactive, but pro-active. Likewise with the views of the second informant, who also stated more or less the same thing. According to him, performing duties as PR should be done in full awareness, understanding the task, so anything that happens a PR will not get panic easily. For him, calm attitude will help PR in solving various problems. To be able to do that, a PR should believe that whatever happens is the will of Allah SWT, so that PR learns from every events happened by being smart in reading (iqra) to take wisdom. According to him, sometimes a PR is tested with a crisis. For him the crisis can actually raise the reputation if the PR is able to respond it well, able to read the situation, and those can only be done in a condition of calm.

Calm attitude is closely related to the ability to self-introspection. In facing the situation that sometimes is unfavorable to the organization, what PR needs to do is self- 
introspection calmly, and do not make the effort to justify blindly, moreover lie to cover up the facts.

The next informant replied that being calm in all situations and conditions does not mean that PR does not do anything. So, calm does not mean silent without doing anything. "PR should be able to conduct self-control and act quickly, responsively, and appropriately in determining the attitude."

7. Patient

Patient has very important position in Islam. The word patient frequently appeared in verses of the Qur'an and Hadith of the Prophet. Patient is the ability of self in facing any situation that is not favored. Patient is one of the work principle that must be owned by PR according to Page.

Patient, according to the first informant, concerned with the ability to listen to complaints and expectations of stakeholders (whose will may vary). Meanwhile, according to the second informant, patient is not just restraint, but about how to admit and to let go. According to him, if patient is only about the ability to restraint then it is not patient. For such patient only delays anger. The delayed anger will be a time bomb in the future.

So, patient is related to the ability to be a human who is aware of his duties and functions in dealing with whatever happens in the world. Patient does not come by itself. Patient needs to be trained, need habituation.

The third informant stated that patient is needed in doing the task and the work. Patient in digging information from the informants, patient in waiting for the development of information, etc. According to him, internally, patient is also necessary when dealing with colleagues, especially for programs involving teamwork. For him, patient is needed to produce something maximally.

\section{Good Humor}

Situations in the work will be stiff when it is done without fresh humor. Therefore, good humor becomes one of the principles of PR work. In various occasions the Prophet also exemplifies how to do fresh humor. Humor can melt the atmosphere. Humor can reduce tension in work and life. Especially for a PR who is required to be flexible in facing various kinds of people. The attitude of humor can certainly melt and familiarize relationships.

Regarding good humor, the four informants gave the same answers. According to them, the ability to perform good humor and in its place is required in the work of a PR. The first informant stated that PR officers should be able to create a comfortable atmosphere and full of intimacy through humor that can enliven the atmosphere. The second informant said that humor does not mean just humor, but acts witty, and that's part of the wisdom. If a PR officer is able to be wise and develop good humor then it does not matter if PR becomes humorous. Being humorous is human. The third infromant stated that humor is creativity. Humor becomes one of options in creativity itself. Humor here is not a joke, but a smart way of reacting situation.

Meanwhile, in Islam, shari'a law is derived from the Qur'an that Allah revealed to the Prophet, and the hadith which contains examples of the behavior and speech of the Prophet who was witnessed or heard by his friends and passed on to friends, tabiin, tabiit tabiin to the Moslems living today.

The awareness of the values of Islamic teachings as law that is very high, greatly affects the working principle of Perhumas members as a PR. For them, the values of Islamic teachings are the guidance in life, the foundation in the preparation of activities. 
Therefore, although PR is required to be able to build good and reputable image through various efforts including sloping the public opinion, it does not mean the PR can justify any means to achieve its goals. There is a law of God that becomes the signs that guide them to do what is and what should not be allowed.

These informants were asked about the 8 principles of public relations proposed by the expert of Public Relations, Arthur W Page. From all the informant's answers as stated in the previous chapter, it can be concluded that the 8 PR principles of W. Page, according to their perceptions, all are in accordance with the teachings of Islam.

The first principle is tell the truth (telling the right thing). All informants agreed that a PR should not lie. Islam firmly teaches its people to be honest, to tell the right thing, as Allah says in Surah Al-Ahzab: 70-71: "You who believe, piety you to Allah and say the true words, Allah will fix up your deeds and forgive your sins. And whoever obeys Allah and His Messenger, then he has indeed triumphed."

The second PR working principle is prove it with action. Conducting proof what they have said. This means that PR should not lie. PR should be able to adjust between what is said and what is done, either by the PR itself and by the organization where he works. In Islam, someone who says or promises something but does not do what he says/promises then it is a lie, treacherous, hypocrite. In this principle, all informants stated that they uphold this principle. They agreed that although they were required to convey good things about the organization, it does not mean they will do it by justifying any means. They will only say things that are true, not artificial. Even if there is something debatable in the public, or something that is unpleasant public, then all they need to do is conveying reasonable arguments, without manipulating the facts. This is certainly in accordance with what Islam taught them. As the word of God in Surah AnNahl verse 105 which says "The truth is that those who lie are those who do not believe in the verses of Allah and they are liars."

The third working principle of $P R$ is listen to the customer. It deals with the principle of listening. Because in an effort to build good relationship with the public organization, a PR is required to have the ability of listening. By listening, the organization through PR will know what the piblic wants. On this matter all informants gave almost the same answers, although with different emphasis. However, all answers indicate that PR should do the listening process, which technically can be done in various ways, ranging from opening the information channel through research.

The fourth working principle that must be owned by PR officers is manage for tomorrow (planning for tomorrow). In Islam, the aspect of planning and preparing the best for tomorrow is compulsory. A plan can not be separated from the effort of managing time. Time is one thing that quickly runs out, will never come back, and become a capital for someone to do their best. Planning deals with what should be done today, tomorrow and the next day. So on and on. In Islam, time has very important position. Even God swears at the beginning of various surahs by mentioning time, like surahs Al-Ashr and Al-lail.

When the four informants were asked for answers to the importance of time management, they all answered that the ability to make a plan and to manage time for various activities is a must for a PR. One of the ideal characteristics of a Moslem believer and cautious lies on his ability to appreciate time. This is implicit in a Qur'anic verse that says "And He (also) who makes night and day take turns for those who want to take a lesson or one who wants to thanks God." (Al-Furqan verse 62). This verse 
indicates that a PR should be able to take lessons and wisdom from the process of changing time.

The next principle that must be owned by a PR according to W. Page is conduct public relations as if the whole company depends on it. In relation to this principle, the four informants answered that the success of maintaining silaturrahmi through efforts to build, to expand, and to strengthen the network to obtain goodwill from the public, is the essence of the work of a PR. In Islam, silaturrahmi which is built sincerely is compulsory. Silaturrahmi can extend life and bring fortune. As the hadith of the Prophet who says "Whoever wants to expand his sustenance and long life, then let him conduct silaturrahim" (Hadith narrated by Bukhari).

A Moslem PR, at the time of performing his duties and functions as the main key in the success of business gaining public support and reputation, not only based on calling of duty but also based on calling of worship.

The working principle that must be owned by PR is remain calm, keep calm and do not "grasa grusu" in every situation and condition. The prophet said: "When you face a problem, you should be calm, then God will show you the way" (Hadith narrated by Bukhari). Calm attitude is closely related to resignation to the Almighty, always returns and asks for help to God. Therefore, the principle of Islamic teachings on calm behavior of course affects the working principle of a Moslem PR. No wonder when they were asked about this principle, the four informants in general conveyed the same thing i.e. good PR should be able to control themselves in all situations, in facing conflict or crisis though. That is one of the qualities that must be owned by those who work as PR.

The last working principle of PR according to W. Page is good humor. PR is dwpartment that is demanded to always look cheerful in front of public as the representatives of the organization. Therefore, a PR should be able to package themselves in such a way to build good relationship. The attitude of humor is one of the ways to melt the atmosphere, and to make others like to be around us. Thus PR will be easier to deliver communications messages in order to build trust and public support. One of the informants even said that humorous attitude is part of wisdom, and being humorous is human.

The prophet, although according to many history he had very little talk except for the things that matter, but on several occasions the Prophet also showed his humor attitude. By reviewing one by one the informants' answers in the chapter of research findings about the principles of public relations according to Arthur W. Page and discussing it by relating it to the teachings in Islam, which become the guideline of life for every Moslem, it can be concluded that the work principle of PR as formulated by Arthur W. Page, had been a long way back existed and became the principles of life for every Moslem. The principles of religious teachings had influenced their work principle as a professional PR.

\section{Conclusion}

The answers of the informants regarding their perception of PR principles according to the Shari'a of Islamic teachings had shown that although they had formal education background and working experience in 4 different institutions, in general they all had the same view of the principles of good work based on the teachings of religion they profess.

Islam as a religion whose teachings they have received for a long time has at least influenced on how they view their profession as a PR. Although Arthur W. Page did not 
elaborate on the 8 principles of PR performance, as a Moslem professional PR, the members of Perhumas Central Java have straight work principle with reference to their religious teachings.

\section{Acknowledgement}

Acknowledgments conveyed to the Directorate of Research and Community Service, Directorate General of Research and Development Strengthening, Ministry of Research, Technology and Higher Education of the Republic of Indonesia (Kemenristekdikti RI) who has funded the author's research with the title "Persepsi Anggota Perhumas Jawa Tengah tentang Prinsip Kinerja Public Relations dalam Pandangan Syariat Islam" (Perception Member Perhumas Central Java on Performance Principles Public Relations in Islamic Shari'a View). This paper is an integral part of the research activities mentioned above.

\section{References}

Al-Qur'an \& Terjemahan. (2007). Mushaf Sahmalnour.

Jefkins, F., Yadin, D. (2002). Public Relations. Jakarta: Erlangga.

Mubarok, Dian, M.K. (2016). Konstruksi Prinsip Kinerja Public Relations dalam Pandangan Syariat Islam. Jurnal The Messenger, 7 (2), 20-34.

Nazir, M. (1988). Metode Penelitian. Jakarta: Ghalia Indonesia.

Sugiyono. (2012). Metode Penelitian Kuantitatif Kualitatif dan R\&D. Bandung: Alfabeta.

Sutopo. (2006). Metodologi Penelitian Kualitatif. Surakarta: UNS.

Syuderajat, F., Prameswari, Y.P. (2017). Program Employee Relations PT. Telkom Indonesia: Kids go to Office. Jurnal The Messenger, 9 (2), 186-193. 